\title{
PALLIATION FOR HILAR CHOLANGIOCARCINOMA: SURGICAL OR NON- OPERATIVE BYPASS? - A CASE REPORT
}

Reddi Hemanthi' ${ }^{1}$ Pindi S. Sitaram²

\section{HOW TO CITE THIS ARTICLE:}

Reddi Hemanthi, Pindi S. Sitaram. "Palliation for Hilar Cholangiocarcinoma: Surgical or Non-operative Bypass?A case report". Journal of Evolution of Medical and Dental Sciences 2015; Vol. 4, Issue 10, February 02;

Page: 1706-1708, DOI: 10.14260/jemds/2015/242

ABSTRACT: The majority of patients with hilar cholangiocarcinoma will have incurable disease at presentation and require only palliation for which a number of surgical and non-operative methods are available but there is no definite consensus to determine the better option. In those patients with life expectancy of more than six months surgical bypass offers good quality and long lasting palliation. This is a single case report of unresectable hilar cholangiocarcinoma in which both endoscopic and surgical bypass procedures have been used for palliation.

KEYWORDS: Hilar cholangiocarcinoma (HC), Endoscopic stenting (ES), Roux-en-y-left hepaticojejunostomy (HJ).

INTRODUCTION: Cholangiocarcinoma is an uncommon malignancy with an incidence of 2.3per lakh population. Hilar cholangiocarcinoma accounts for up to $80 \%$ of these tumors and the overall prognosis is poor with a mean survival of 21 months. Majority of these cases present with locally advanced irresectable disease. They suffer from progressive jaundice, pruritis, recurrent cholangitis leading to septicemia or liver failure and death ensues. They require palliative biliary decompression, either surgical or endoscopic, to relieve their symptoms. Aim of palliation is to optimize the quality and quantity of remaining life with minimal morbidity and mortality.

CASE REPORT: A 48 year old female presented with progressive jaundice, cholangitis and troublesome pruritis of 1 month duration. Her LFT report was Total bilirubin $-19.6 \mathrm{mg} / \mathrm{dl}$ with direct $16.4 \mathrm{mg} / \mathrm{dl} \&$ indirect $3.2 \mathrm{mg} / \mathrm{dl}$, SGOT-200 IU/L, SGPT - 376 IU/L,ALP-299 IU/L.CECT abdomen showed dilated CBD of $9 \mathrm{~mm}$ diameter, moderate IHBD, cholelithiasis, hypodense area at confluence suspicious of malignant stricture. ERCP showed dilated left and right hepatic ducts with stricture below confluence across which a $10 \mathrm{Fr}$ x $10 \mathrm{~cm}$ straight Tannenbaum plastic stent was placed. Post stenting bilirubin decreased to $8 \mathrm{mg} / \mathrm{dl}$. Patient returned with deepening jaundice and cholangitis 40 days after stenting. She was subjected to endoscopic stent change and a10Frx $10 \mathrm{~cm}$ percuflex biliary stent was placed, which again got obstructed after 30 days.

Because of the very short duration of stent patency a more durable left hepaticojejunostomy was planned. Pre-operative investigations showed Serum total bilirubin-19.6mg/dl, direct bilirubin $13.3 \mathrm{mg} / \mathrm{dl}$, indirect $6.3 \mathrm{mg} / \mathrm{dl}$, alkaline phosphatase $-333 \mathrm{IU} / \mathrm{L}$, serum proteins $-6.7 \mathrm{gm}$ and $\mathrm{A} / \mathrm{G}$ ratio 0.8.MRCP showed Left hepatic duct $-8 \mathrm{~mm}$ and Right hepatic duct $-7 \mathrm{~mm}$ diameter.(Fig $1 \& 2$ )

Under general anaesthesia access was gained through a right subcoastal incision. Laparotomy findings were a grossly distended gall bladder with its neck and cystic duct encased in dense fibrosis and plastered posteriorly. Thick hard stricture palpable for $2 \mathrm{~cm}$ length involving common hepatic duct (CHD) and confluence - Type II Bismuth tumor(fig.3 \&4).Left hepatic duct was isolated, it was $9 \mathrm{~mm}$ in diameter and $1.2 \mathrm{~cm}$ in length. A Roux loop was fashioned from proximal jejunum and a Roux- 


\section{CASE REPORT}

en-y-left hepaticojejunostomy was done (fig. 5). Post-operative recovery was good, serum bilirubin level dropped to $1.4 \mathrm{mg} / \mathrm{dl}$ at the time of discharge on the $8^{\text {th }}$ postoperative day. Patient was followed up for 9 months period during which the serum bilirubin level remained less than $1.5 \mathrm{mg} / \mathrm{dl} \&$ pruritis relieved. Thus the patient had a longer symptom free interval of 9 months after surgery compared to only 40 days after endoscopic stenting.

DISCUSSION: To relieve hyperbilirubinemia, 30-50\% of functioning liver needs to be drained. This can be achieved by surgical or percutaneous or endoscopic biliary drainage procedures. Nonoperative decompressions are indicated in patients with poor surgical risks and in patients with life expectancy less than 6 months due to extensive disease or multiple metastasis. In patients other than these, surgical biliary bypass offers more durable palliation.

Endoscopic retrograde biliary decompression can be achieved using plastic or metal stents. Plastic stents of 10-12 Fr diameter have an average duration of patency of 3-4 months. Their advantage is low cost, simple insertion and easy removal but the disadvantage is ease of clogging requiring frequent stent changing every 2-4 months. Self-expanding metal stents (SEMS) have large internal diameter of $30 \mathrm{Fr}$, patency duration of 10 months and allow drainage of secondary branches through open side mesh of stent. Their disadvantage is high price and chance of tumor ingrowth into stent lumen with uncovered SEMS.

Surgical palliation is by enteric anastomosis to the extrahepatic or selected intrahepatic segmental ducts, mainly segment III. These include Roux-en-y- left hepaticojejunostomy, segment III cholangiojejunostomy and right sided hepaticojejunostomy. Left hepaticojejunostomy is easier of the three. The left hepatic duct (LHD) is extrahepatic in its course and has a mean length of $1.3 \mathrm{~cm}$. It runs transversely at the base of segment IV and can be exposed by retracting segment IV cranially. To gain access to LHD,a plane between Glissons capsule and the peritoneal extension encasing the portal triad at the base of segment IV requires division. The duct is incised longitudinally for the length exposed,a retrocolic Roux limb is fashioned from proximal jejunum and a side-side,single layer, interrupted, mucosal to mucosal anastomosis is performed using 4.0 monofilament suture material.

CONCLUSION: Majority of patients with hilar cholangiocarcinoma will require a palliative approach. In those with a life expectancy of less than six months and those unfit for surgery non-surgical stenting is a preferred treatment, but patients other than these are likely to achieve better quality palliation with surgery, which can be performed with similar mortality \& morbidity to non-operative techniques.

\section{BIBLIOGRAPHY:}

1. Schwartz's principles of surgery, $8^{\text {th }}$ edition, The Mc Graw-Hill Companies, 2005.

2. Blumgart L.H. Surgery of the Liver, Biliary tract \& Pancreas, $4^{\text {th }}$ edition, Saunders Elseiver, 2007.

3. Nordback IH, Pitt HA, Coleman J, Venbrux AC, et al. unresectable hilar cholangiocarcinoma: percutaneous vs operative palliation.Surgery.1994; 115: 597-603[pubMed].

4. Kuvshin off BW, Armstrong JG,Fong Y,et al.palliation of irresectable cholangiocarcinoma.Br J Surg. 1995.

5. Bismuth H, Malt RA, Carcinoma of biliary tree. N Engl J Med. 1979. 


\section{CASE REPORT}

6. Li HM, Dou KF, Sun K, et al. Palliative surgery for hilar cholangiocarcinoma. Hepatobiliary Pancreat Dist. Int. 2003.

7. Boris R. A. Belchacz, Gregory J. Gores: Cholangiocarcinoma, Clinics in liver disease, Elseiver Saunders, 2005.

8. Renshaw K. Malignant neoplasm of extrahepatic biliary ducts Ann Surg 1992; 76: 205-21.

\section{AUTHORS:}

1. Reddi Hemanthi

2. Pindi S. Sitaram

\section{PARTICULARS OF CONTRIBUTORS:}

1. Assistant Professor, Department of General Surgery, Rangaraya Medical College, Kakinada.

2. Assistant Professor, Department of General Surgery, Rangaraya Medical College, Kakinada.

\section{NAME ADDRESS EMAIL ID OF THE} CORRESPONDING AUTHOR:

Dr. R. Hemanthi,

Vennela ENT Hospital,

Kakinada-533003.

E-mail: reddihemanthi@gmail.com

Date of Submission: 09/01/2015.

Date of Peer Review: 10/01/2015.

Date of Acceptance: 22/01/2015.

Date of Publishing: 02/02/2015. 